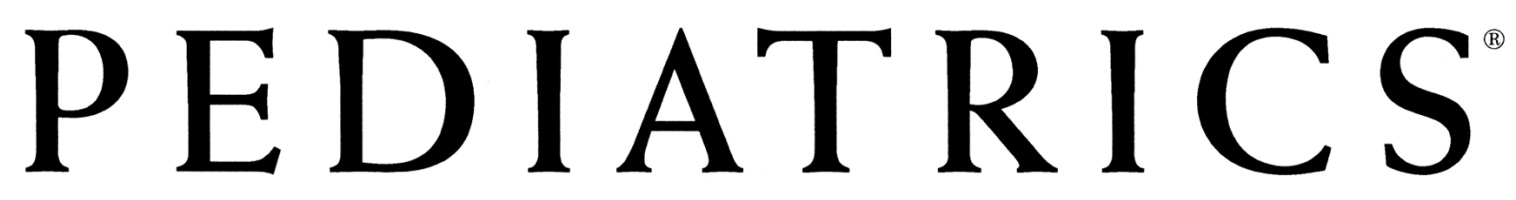

OFFICIAL JOURNAL OF THE AMERICAN ACADEMY OF PEDIATRICS

\title{
Childhood Helicobacter pylori Infection and Growth Impairment in Developing Countries: A Vicious Cycle?
}

Henry J. Windle, Dermot Kelleher and Jean E. Crabtree

Pediatrics 2007;119; e754-e759; originally published online Feb 26, 2007;

DOI: $10.1542 /$ peds.2006-2196

The online version of this article, along with updated information and services, is located on the World Wide Web at:

http://www.pediatrics.org/cgi/content/full/119/3/e754

PEDIATRICS is the official journal of the American Academy of Pediatrics. A monthly publication, it has been published continuously since 1948. PEDIATRICS is owned, published, and trademarked by the American Academy of Pediatrics, 141 Northwest Point Boulevard, Elk Grove Village, Illinois, 60007. Copyright @ 2007 by the American Academy of Pediatrics. All rights reserved. Print ISSN: 0031-4005. Online ISSN: 1098-4275.

\section{American Academy of Pediatrics}

DEDICATED TO THE HEALTH OF ALL CHILDREN ${ }^{m}$ 


\section{Childhood Helicobacter pylori Infection and Growth Impairment in Developing Countries: A Vicious Cycle?}

Henry J. Windle, PhDa, Dermot Kelleher, MD, FRCPa, Jean E. Crabtree, DPhil, MRCPath ${ }^{\text {b }}$

aSchool of Medicine, Trinity College Dublin and Dublin Molecular Medicine Centre, Dublin, Ireland; bLeeds Institute of Molecular Medicine Unit, St James's University Hospital, Leeds, United Kingdom

The authors have indicated they have no financial relationships relevant to this article to disclose.

ABSTRACT

We hypothesize that infection with the gastric pathogen Helicobacter pylori in children in developing countries is the initiator of a vicious cycle of events that result ultimately in malnutrition and growth impairment. Acute infection with $H$ pylori is accompanied by hypochlorhydria, which facilitates the acquisition of other enteropathogens because of removal of the gastric acid barrier, which then results in diarrheal disease and iron-deficiency anemia. This is likely to occur most frequently in developing regions where the prevalence of $H$ pylori infection is disproportionately high and multiple enteric coinfections are common. The consequent synergistic impact of diarrheal disease and micronutrient deficiency on growth and cognitive function in children has significant public health implications for socioeconomic development in these countries.

www.pediatrics.org/cgi/doi/10.1542/ peds.2006-2196

doi:10.1542/peds.2006-2196

\section{Key Words}

H pylori, hypochlorhydria, diarrhea, enteric infections, iron-deficiency anemia,

malnutrition

\section{Abbreviations}

IDA-iron-deficiency anemia

IL-1-interleukin 1

Accepted for publication Oct 3, 2006

Address correspondence to Jean E. Crabtree, DPhil, MRCPath, Leeds Institute of Molecular Medicine, Level 9 Molecular Medicine Section, St James's University Hospital, Leeds LS9 7TF,

United Kingdom. E-mail: j.crabtree@leeds.ac. uk

PEDIATRICS (ISSN Numbers: Print, 0031-4005; Online, 1098-4275). Copyright $\odot 2007$ by the American Academy of Pediatrics 
$\mathrm{T}$ HE ACQUISITION OF Helicobacter pylori infection occurs primarily in early childhood. Acute infection, at least in adults, results in a transient or extended period of hypochlorhydria. We hypothesize that this period represents a critical phase for pediatric cohorts in developing countries because, within this window, the individual becomes more susceptible to (1) acquiring other enteropathogenic infections, which results in diarrheal illness, and (2) developing iron-deficiency anemia (IDA). The combined impact of these extragastric manifestations of $H$ pylori infection ultimately results in impaired childhood growth and cognitive function caused by the comorbidity associated with malnutrition, micronutrient deficiency, and diarrheal disease.

\section{EVIDENCE FOR OUR HYPOTHESIS}

Since the discovery of $H$ pylori by recent Nobel Laureates Marshall and Warren ${ }^{1}$ in 1982, the pathogen has been shown to be a causative agent of disease states of varying degrees of severity including chronic gastritis, peptic ulcer disease, gastric adenocarcinoma, and gastric mucosaassociated lymphoid tissue (MALT) lymphoma. Host genetics, host immune responses, and bacterial virulence factors contribute to the multifactorial nature of disease progression. ${ }^{2-4}$ Interleukin (IL) $-1 \beta$ is a potent suppressor of gastric acid secretion, and polymorphisms in the $I L-1$ gene cluster resulting in high IL- $1 \beta$ production are associated with hypochlorhydria with chronic $H$ pylori infection. ${ }^{2}$ More severe disease is also associated with specific bacterial factors such as the cag pathogenicity island ${ }^{5}$ and carriage of specific alleles of the vacuolating cytotoxin. ${ }^{6}$

Although the discovery of $H$ pylori ${ }^{1}$ heralded a major reevaluation of the etiology of peptic ulcer disease and distal gastric cancer, the major global impact of $H$ pylori infection may yet be largely unrecognized. In developing countries the incidence of $H$ pylori infection in infancy is high $^{7-10}$ and has been associated with malnutrition and growth faltering. ${ }^{11,12}$ Indeed, the incidence of $H$ pylori infection in malnourished children is greater than in adequately nourished subjects. ${ }^{13}$ Moreover, there is an inverse relationship between early $H$ pylori colonization, infant malnutrition, and socioeconomic status. ${ }^{14}$ It is believed that the acquisition of $H$ pylori in infancy/childhood in developing countries has a more severe impact on general health compared with developed countries. We believe that the acquisition of $H$ pylori in childhood in developing countries is the initiator of a vicious cycle of events that makes an impact on childhood morbidity and mortality, as summarized in Fig 1.

First, the association between acute $H$ pylori infection and transient hypochlorhydria in adults is well documented. ${ }^{15-24}$ Hypochlorhydria usually resolves within several months. Experimental infection of animals with gastric Helicobacter species also results in initial hypochlorhydria, ${ }^{25-27}$ which in gerbils was reversible by treatment

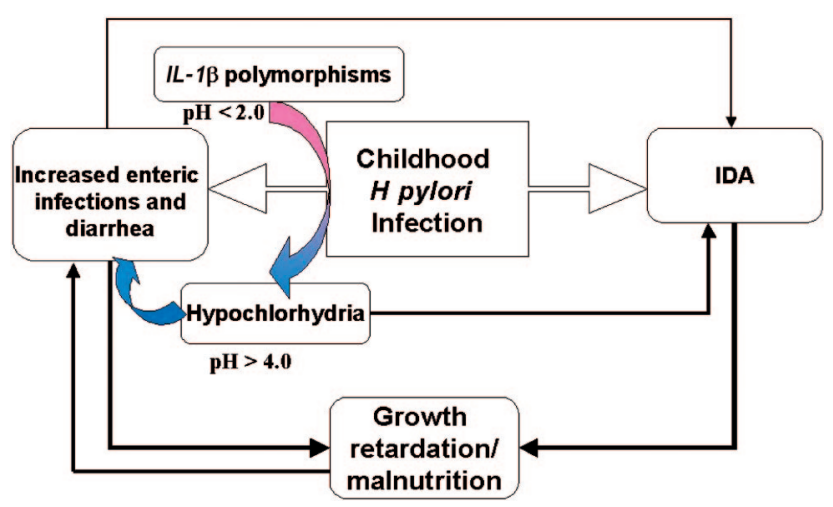

FIGURE 1

Potential cycle induced by childhood $\mathrm{H}$ pylori infection in developing countries. H pylori infection and hypochlorhydria result in development of IDA and acquisition of other enteric infections, which promotes a vicious cycle of malnutrition and growth impairment. Polymorphisms in the $\mathbb{L}-1 \beta$ gene cluster may control the extent and duration of hypochlorhydria with initial $\mathrm{H}$ pylori infection.

with recombinant IL-1 receptor antagonist. ${ }^{26}$ It is interesting to note that animal models have shown that hypochlorhydria can promote fecal transmission of infection, ${ }^{27}$ an observation that may have implications for $H$ pylori transmission among humans. However, although there is less direct evidence to support an association between acute $H$ pylori infection and hypochlorhydria in pediatric cohorts, accumulating evidence indicates that $H$ pylori-infected children also have impaired gastric acid secretion. ${ }^{28-33}$

Second, hypochlorhydria increases susceptibility to enteric infections ${ }^{34,35}$ such as typhoid and nontyphoidal salmonellosis, ${ }^{36,37}$ cholera, ${ }^{38-42}$ giardiasis, ${ }^{43}$ and other infections. Other organisms (eg, Escherichia coli, Shigella flexneri) are less susceptible to gastric acid and can survive exposure to acidic $\mathrm{pH} .{ }^{44}$ Evidence from case-controlled studies that examined the association between proton pump inhibitor-induced hypochlorhydria and increased relative risk of acquiring enteric infections including Clostridium difficile, Giardia, and Salmonella supports the view that a reduction in gastric acid secretion may result in the acquisition of infections, as reviewed elsewhere $^{45,46}$ (see Table 1). Thus, H pylori-induced hypochlorhydria may predispose to enteric infections, ${ }^{58}$ particularly in regions of the developing world where enteric infections are endemic. Evidence from develop-

TABLE 1 Association of Proton Pump-Inhibitor Use With Increased Risk of Gastrointestinal Infection/Gastroenteritis

\begin{tabular}{lcc}
\hline Infecting Organism & Odds Ratio & References \\
\hline Cdifficile & $1.9-2.9$ & $47-52$ \\
Gastroenteritis (ND) & $1.8-5$ & 53 \\
Salmonella & 4.6 & 54 \\
Campylobacter & 11.7 & 55 \\
Giardia & - & 52 and 56 \\
Gastroenteritis (ND) & 3.58 & 57 \\
\hline
\end{tabular}

ND indicates no infecting organism determined; - , not reported. 
ing countries indicates that $H$ pylori infection may increase the risk of acquisition of coinfection with other pathogens including Vibrio cholerae,, 59,60 Salmonella typhi, ${ }^{61,62}$ Shigella, ${ }^{63}$ and various parasites. ${ }^{64}$ The resultant diarrhea post-acute $H$ pylori infection ${ }^{13,29,65}$ leads to malnutrition and growth retardation in children. ${ }^{29,66-70}$ The recent linking of enteric protozoal infections in developing countries with impaired cognitive function in children $^{71}$ further emphasizes the importance of the vicious cycle initiated by $H$ pylori on childhood morbidity and potential for socioeconomic impairment.

Another potential consequence of hypochlorhydria is IDA. IDA is a major public health issue, particularly in children, in developing countries where the prevalence in these regions exceeds $50 \%$. In addition to poor nutritional sources of iron in many regions, absorption of bioavailable iron can be compromised if there are alterations to gastric acid secretion (eg, see ref 58). Acidic $\mathrm{pH}$ is essential for the efficient reduction and complexation of iron (and other micronutrients) before absorption..$^{72,73}$

A possible causal role for $H$ pylori in the onset of IDA is supported by epidemiologic studies in adults ${ }^{74-78}$ and children. ${ }^{79-84}$ A combination of the (1) hypochlorhydriaassociated $H$ pylori infection and (2) direct competition between $H$ pylori and the host for iron are the likely main contributors to IDA. ${ }^{85-89}$ In developing regions, the micronutrient deficiency and clinical sequelae would be further exacerbated by malnutrition and concurrent enteric infections. ${ }^{90,91}$ Manifestations of clinically advanced IDA include increased childhood mortality and susceptibility to disease, reduced growth, ${ }^{11,18}$ and cognitive function. ${ }^{92}$ However, the impact of $H$ pylori on acquisition of diarrheal pathogens and pediatric growth in developing countries has not yet been evaluated rigorously. Studies in developed countries on the role of $H$ pylori in diarrheal illness ${ }^{93,94}$ have yielded conflicting results compared with those in developing countries. ${ }^{59,61-63}$ This is perhaps not surprising, given the markedly contrasting exposure to diarrheal pathogens in developing countries. To date, few studies have focused on children during the first few years of life, which is when acute $H$ pylori infection and associated hypochlorhydria occur.

\section{CONCLUSIONS}

A combination of micronutrient deficiency and coinfection with diarrhea-inducing enteropathogens acquired as a consequence of $H$ pylori-induced hypochlorhydria is likely to have a profound impact on pediatric populations in developing countries where the prevalence of $H$ pylori is high and reliable nutritional sources of bioavailable iron are low. Thus, prevention of $H$ pylori infection could potentially have an important impact on diarrheal diseases in the developing world.

\section{TESTING THE HYPOTHESIS}

Whether the hypochlorhydria induced by acute $H$ pylori infection in childhood is associated with an increase in enteric infections and diarrheal disease, IDA, and growth impairment remains an important unanswered question. The impact of $I L-1 \beta$ gene cluster polymorphisms on acute $H$ pylori infection-related hypochlorhydria in pediatric populations is unknown. These factors require evaluation by a multicountry longitudinal observational prospective cohort study in developing countries to determine the impact of $H$ pylori and other enteropathogen infections on the epidemiology of diarrheal disease, IDA, and childhood growth. As a causative agent of human disease, the global impact of $H$ pylori on childhood morbidity in developing counties may far outreach its role in causing peptic ulcer disease and gastric cancer.

\section{ACKNOWLEDGMENTS}

Work in the laboratories of Drs Windle and Kelleher is supported by the Health Research Board, Enterprise Ireland, the European Union, and the Higher Education Authority. Work in the laboratory of Dr Crabtree is supported by Yorkshire Cancer Research and the European Union. We are funded under the Sixth Framework Program of the European Union, Project CONTENT (INCO-CT-2006-032136).

\section{REFERENCES}

1. Marshall BJ, Warren JR. Unidentified curved bacilli in the stomach of patients with gastritis and peptic ulceration. Lancet. 1984;1(8390):1311-1315

2. Furuta T, El-Omar EM, Xiao F, Shirai N, Takashima M, Sugimurra H. Interleukin lbeta polymorphisms increase risk of hypochlorhydria and atrophic gastritis and reduce risk of duodenal ulcer recurrence in Japan. Gastroenterology. 2002;123: 92-105

3. Queiroz DM, Bittencourt P, Guerra JB, Rocha AM, Rocha GA, Carvalho AS. ILIRN polymorphism and cagA-positive Helicobacter pylori strains increase the risk of duodenal ulcer in children. Pediatr Res. 2005;58:892-896

4. Peek RM Jr, Crabtree JE. Helicobacter infection and gastric neoplasia. J Pathol. 2006;208:233-248

5. Crabtree JE, Taylor JD, Wyatt JI, et al. Mucosal IgA recognition of Helicobacter pylori $120 \mathrm{kDa}$ protein, peptic ulceration, and gastric pathology. Lancet. 1991;338:332-325

6. Atherton JC, Cao P, Peek RM Jr, Tummuru MK, Blaser MJ, Cover TL. Mosaicism in vacuolating cytotoxin alleles of Helicobacter pylori: association of specific vacA types with cytotoxin production and peptic ulceration. J Biol Chem. 1995;270: 17771-17777

7. Mergraud F, Brassens-Rabbe MP, Denis F, Belbouri A, Hoa DQ. Seroepidemiology of Campylobacter pylori infection in various populations. J Clin Microbiol. 1989;27:1870-1873

8. Kehrt R, Becker M, Brosicke H, Kruger N, Helge H. Prevalence of Helicobacter pylori infection in Nicaraguan children with persistent diarrhoea, diagnosed by the C-13 urea breath test. J Pediatr Gastroenterol Nutr. 1997;25:84-88

9. Goodman K, Correa P, Tengana Aux HJ, et al. Helicobacter infection in the Columbian Andes: a population based study of transmission pathways. Am J Epidemiol. 1996;144:290-299

10. Sarker SA, Rahman MM, Mahalanabis D, et al. Prevalence of 
Helicobacter pylori infection in infants and family contacts in a poor Bangladeshi community. Dig Dis Sci. 1995;40:2669-2672

11. Thomas JE, Dale A, Bunn JEG, et al. Early Helicobacter pylori colonisation: the association with growth faltering in the Gambia. Arch Dis Child. 2004;89:1 149-1154

12. Mera RM, Correa P, Fontham EE, et al. Effects of a new Helicobacter pylori infection on height and weight in Columbian children. Ann Epidemiol. 2006;16:347-351

13. Sullivan PB, Thomas JE, Wight DGD, et al. Helicobacter pylori in Gambian children with chronic diarrhoea and malnutrition. Arch Dis Child. 1990;65:189-191

14. Webb PM, Knight T, Greaves S, et al. Relation between infection with Helicobacter pylori and living-conditions in childhood. BMJ. 1994;308:750-753

15. Graham DY, Alpert LC, Smith JL, Yoshimura HH. Iatrogenic Campylobacter pylori infection is a cause of epidemic achlorohydria. Am J Gastroenterol. 1988;83:974-980

16. McColl KE, El-Omar EM, Gillen D. Interactions between $H$. pylori infection, gastric acid secretion and anti-secretory therapy. Br Med Bull. 1998;54:121-138

17. McColl KE, El-Omar EM, Gillen D. Alterations in gastric physiology in Helicobacter pylori infection: causes of different diseases or epiphenomena? Ital J Gastroenterol Hepatol. 1997;29: 459-464

18. El-Omar EM, Oien K, El-Nujumi A, et al. Helicobacter pylori infection and chronic gastric acid hyposecretion. Gastroenterology. 1997;113:15-24

19. Morris A, Nicholson G. Ingestion of Campylobacter pyloridis causes gastritis and raised fasting gastric $\mathrm{pH}$. Am J Gastroenterol. 1987;82:192-199

20. Sobala GM, Crabtree JE, Dixon MF, et al. Acute Helicobacter pylori infection: clinical features, local and systemic immune response, gastric mucosal histology, and gastric juice ascorbic acid concentrations. Gut. 1991;32:1415-1418

21. Ramsey EJ, Carey KV, Peterson WL, et al. Epidemic gastritis with hypochlorhydria. Gastroenterology. 1979;76:1449-1457

22. Gledhill T, Leicester R, Addis B, et al. Epidemic hypochlorhydria. Br Med J (Clin Res Ed). 1985;290:1383-1386

23. Harford WV, Barnett C, Lee E, Perez-Perez G, Blaser MJ, Peterson WL. Acute gastritis with hypochlorhydria: report of 35 cases with long term follow up. Gut. 2000;47:467-472

24. Iijima K, Ohara S, Sekine $\mathrm{H}$, et al. Changes in gastric acid secretion assayed by endoscopic gastrin test before and after Helicobacter pylori eradication. Gut. 2000;46:20-26

25. Fox JG, Otto G, Taylor NS, Rosenblad W, Murphy JC. Helicobacter mustelae-induced gastritis and elevated gastric $\mathrm{pH}$ in the ferret (Mustela putorius furo). Infect Immun. 1991;59:1875-1880

26. Takashima M, Furuta T, Hanai H, Sugimura H, Kaneko E. Effects of Helicobacter pylori infection on gastric acid secretion and serum gastrin levels in Mongolian gerbils. Gut. 2001;48: 765-773

27. Fox JG, Blanco MC, Yan L, et al. Role of gastric pH in isolation of Helicobacter mustelae from the feces of ferrets. Gastroenterology. 1993; 104:86-92

28. Sarker SA, Davidsson L, Mahmud H, et al. Helicobacter pylori infection, iron absorption, and gastric acid secretion in Bangladeshi children. Am J Clin Nutr. 2004;80:149-153

29. Dale A, Thomas JF, Darboe MK, Coward WA, Harding M, Weaver LT. Helicobacter pylori infection, gastric acid secretion, and infant growth. J Pediatr Gastroenterol Nutr. 1998;26: 393-397

30. Weaver LT. Royal Society of Tropical Medicine and Hygiene Meeting at Manson House, London, 16 February 1995: Aspects of Helicobacter pylori infection in the developing and developed world-Helicobacter pylori infection, nutrition and growth of West African infants. Trans R Soc Med Hyg. 1995;89:347-350

31. Park JH, Kim SY, Kim DW, Lee WG, Rhee KH, Youn HS.
Correlation between Helicobacter pylori infection and vitamin C levels in whole blood, plasma, gastric juice, and the $\mathrm{pH}$ of gastric juice in Korean children. J Pediatr Gastroenterol Nutr. 2003; 37:53-62

32. McCallion WA, Ardill JE, Bamford KB, Potts SR, Boston VE. Age dependent hypergastrinaemia in children with Helicobacter pylori gastritis: evidence of early acquisition of infection. Gut. 1995; $37: 35-38$

33. Baysoy G, Ertem D, Ademoglu E, Kotiloglu E, Keskin S, Pehlivanoglu E. Gastric histopathology, iron status and iron deficiency anaemia in children with Helicobacter pylori infection. J Pediatr Gastroenterol Nutr. 2004;38:146-151

34. Howden CW, Hunt RH. The relationship between gastric acid secretion and infection. Gut. 1987;28:96-107

35. Gilman RH, Partanen R, Brown KH, et al. Decreased gastric acid secretion and bacterial colonisation of the stomach of severely malnourished Bangladeshi children. Gastroenterology. 1988;94:1308-1314

36. Giannella RA, Broitman SA, Zamcheck N. Salmonella enteritis: role of reduced gastric secretion in pathogenesis. Am J Dig Dis. 1971;16:1000-1006

37. Khosla SN, Jain N, Khosla A. Gastric acid secretion in typhoid fever. Postgrad Med J. 1993;69:121-123

38. Nalin DR, Levin RJ, Levine MM, et al. Cholera, non-Vibrio cholera and stomach acid. Lancet. 1978;2(8095):856-859

39. Sack GH, Pierce NF, Hennessey KN, Mitra RC, Sack RB, Mazumder DNG. Gastric acidity in cholera and noncholera diarrhoea. Bull World Health Organ. 1972;47:31-36

40. Cash RA, Music SI, Libonati JP, Snyder MJ, Wenzel RP, Hoenick RB. Response of man to infection with Vibrio cholera: clinical, serological, and bacteriologic responses to a known inoculum. J Infect Dis. 1974;129:45-52

41. Evans CA, Gilman RH, Rabbani GH, Salazar G, Ali A. Gastric acid secretion and enteric infection in Bangladesh. Trans $R$ Soc Trop Med Hyg. 1997;91:681-685

42. Shahinian ML, Passaro DJ, Swerdlow DL, Mintz ED, Rodriguez M, Parsonnet J. Helicobacter pylori and epidemic Vibrio cholera 01 infection in Peru. Lancet. 2000;355:377-378

43. Cook GC. Infective gastroenteritis and its relationship to reduced gastric acidity. Scand J Gastroenterol Suppl. 1985;111: $17-23$

44. Lin J, Lee IS, Frey J, Slonczewski JL, Foster JW. Comparative analysis of extreme acid survival in Salmonella typhimurium, Shigella flexneri, and E. coli. J Bacteriol. 1995;177:4097-4104

45. Martinsen TC, Bergh K, Waldum HL. Gastric juice: a barrier against infectious disease. Basic Clin Pharmacol Toxicol. 2005;96: 94-102

46. Laine L, Ahnen D, McLain C, Solcia E, Walsh JH. Review article: potential gastrointestinal effects of long-term acid suppression with proton pump inhibitors. Aliment Pharmacol Ther. 2000; 14:651-668

47. Dial S, Alrasadi K, Manoukian C, Huang A, Menzies D. Risk of Clostridium difficile diarrhea among hospital inpatients prescribed proton pump inhibitors: cohort and case-control studies. CMAJ. 2004;171:33-38

48. Dial S, Delaney JA, Barkun AN, Suissa S. Use of gastric acidsuppressive agents and the risk of community-acquired Clostridium difficile-associated disease. JAMA. 2005;294:2989-2995

49. Yearsley KA, Gilby LJ, Ramadas AV, Kubiak EM, Fone DL, Allison MC. Proton pump inhibitor therapy is a risk factor for Clostridium difficile-associated diarrhoea. Aliment Pharmacol Ther. 2006;24:613-619

50. Cunningham R, Dale B, Undy B, Gaunt N. Proton pump inhibitors as a risk factor for Clostridium difficile diarrhoea. J Hosp Infect. 2003;54:243-245

51. Black RE, Levine MM, Clements ML, Hughes TP, Blaser MJ. 
Experimental Campylobacter jejuni infections in humans. J Infect Dis. 1988; 157:472-479

52. Khatami SS, Mukunda B, Ravakhah K. Co-infection with Giardia lamblia and Clostridium difficile after use of ranitidine. Am J Med Sci. 2004;327:91-93

53. Nwoloko C, Loft D, Holder R, Langman M. Increased incidence of bacterial diarrhoea in patients taking gastric acid antisecretory drugs. Eur J Clin Gastroenterol Hepatol. 1994;6:693-699

54. Neal KR, Briji SO, Slack RC, Hawkey CJ, Logan RF. Recent treatment with $\mathrm{H} 2$ antagonists and antibiotics and gastric surgery as risk factors for salmonella infection. BMJ. 1994;308:176

55. Neal KR, Scott HM, Slack RCB, Logan R. Omeprazole as a risk factor for Campylobacter gastroenteritis: a case control study. BMJ. 1996;312:414-415

56. Reynaert H, Fernandes E, Bourgain C, Smekens L, Devis G. Proton pump inhibition and gastric giardiasis: a causal or casual association? J Gastroenterol. 1995;30:775-778

57. Canani RB, Cirillo P, Roggero P, et al. Therapy with gastric acidity inhibitors increases the risk of acute gastroenteritis and community acquired pneumonia in children. Pediatrics. 2006; 117(5). Available at: www.pediatrics.org/cgi/content/full/1 17/ 5/e817

58. Sarker SA, Gyr K. Non-immunological defence mechanisms of the gut. Gut. 1992;33:987-993

59. Clemens J, Albert MJ, Rao M, et al. Impact of infection by Helicobacter pylori on the risk and severity of endemic cholera. J Infect Dis. 1995;171:1653-1656

60. Leon-Barua R, Recavarren-Arce S, Chinga-Alayo E, et al. Helicobacter pylori-associated chronic atrophic gastritis involving the gastric body and severe disease by Vibrio cholerae. Trans Roy Soc Trop Med Hyg. 2006;100:567-572

61. Bhan MK, Bahl R, Sazawai S, et al. Association between Helicobacter pylori infection and increased risk of typhoid fever. J Infect Dis. 2002;186:1857-1860

62. Vollaard AM, Verspaget HW, Ali S, Visser LG, et al. Helicobacter pylori infection and typhoid fever in Jakarta, Indonesia. Epidemiol Infect. 2006;134:163-170

63. Shmuely H, Samra Z, Ashkenazi S, Dinari G, Chodick G, Yahav J. Association of Helicobacter pylori infection with Shigella gastroenteritis in young children. Am J Gastroenterol. 2004;99: 2041-2045

64. Torres J, Perez GP, Ximinez C, et al. Association of intestinal parasitosis and $H$. pylori infection in children and adults from a Mexican community with high prevalence of parasitosis. Helicobacter. 2003;8:179-185

65. Passaro DJ, Taylor DN, Meza R, Cabrera L, Gilman RH, Parsonnet J. Acute Helicobacter pylori infection is followed by an increase in diarrheal disease among Peruvian children. Pediatrics. 2001;108(5). Available at: www.pediatrics.org/cgi/ content/full/108/5/e87

66. Bravo LE, Mera R, Reina JC, et al. Impact of Helicobacter pylori infection on growth of children: a prospective cohort study. J Pediatr Gastroenterol Nutr. 2003;37:614-619

67. Passaro DJ, Taylor DN, Gilman RH, Cabrera L, Parsonnet J. Growth slowing after acute Helicobacter pylori infection is agedependent. J Pediatr Gastroenterol Nutr. 2002;35:522-526

68. Choe YH, Kim SK, Hong YC. Helicobacter pylori infection with iron deficiency anaemia and subnormal growth at puberty. Arch Dis Child. 2000;82:136-140

69. Demir H, Saltik IN, Kocak N, Yuce A, Ozen H, Gurakan F. Subnormal growth in children with Helicobacter pylori infection. Arch Dis Child. 2001;84:89-90

70. Tasar A, Kibrisli E, Dallar Y. Seroprevalence of Helicobacter pylori in children with constitutional height retardation. Turk $J$ Gastroenterol. 2006; 17:7-12

71. Berkman DS, Lescano AG, Gilman RH, Lopez SL, Black MM. Effects of stunting, diarrhoeal disease, and parasitic infection during infancy on cognition in late childhood: a follow-up study. Lancet. 2002;359:564-571

72. Skikine BS, Lynch SR, Cook JK. Role of gastric acid in food iron absorption. Gastroenterology. 1981;81:1068-1071

73. Conrad ME, Umbreit JN, Moore EG. Iron absorption and transport. Am J Med Sci. 1999;318:213-219

74. Yakoob J, Jafri W, Abid S. Helicobacter pylori infection and micronutrient deficiencies. World J Gastroenterol. 2003;9: 2137-2139

75. Cardenas VM, Mulla ZD, Ortiz M, Graham, DY. Iron deficiency and Helicobacter pylori infection in the United States. Am J Epidemiol. 2006;163:127-134

76. DuBois S, Kearney DJ. Iron-deficiency anaemia and Helicobacter pylori infection: a review of the evidence. Am J Gastroenterol. 2005; 100:453-459

77. Milman N, Rosenstock S, Andersen L, Jorgensen T, Bonnevie O. Serum ferritin, hemoglobin, and Helicobacter pylori infection: a seroepidemiologic survey comprising 2794 Danish adults. Gastroenterology. 1998;115:268-274

78. Parkinson AJ, Gold BD, Bulkow L, et al. High prevalence of Helicobacter pylori infection in the Alaska native population and association with low serum ferritin levels in young adults. Clin Diagn Lab Immunol. 2000;7:885-888

79. Konno M, Muraoka S, Takahashi M, Imai T. Iron-deficiency anemia associated with Helicobacter pylori gastritis. J Pediatr Gastroentrol Nutr. 2000;31:52-56

80. Choe YH, Kim SK, Son BK, Lee DH, Hong YC, Pai SH. Randomized placebo-controlled trial of Helicobacter pylori eradication for iron-deficiency anemia in preadolescent children and adolescents. Helicobacter. 1999:4:135-139

81. Barabino A, Dufour C, Marino CE, Claudiani F, De Alessandri A. Unexplained refractory iron-deficiency anemia associated with Helicobacter pylori gastric infection in children: further clinical evidence. J Pediatr Gastroenterol Nutr. 1999;28:116-119

82. Baggett HC, Parkinson AJ, Muth PT, Gold BD, Gessner BD. Endemic iron deficiency associated with Helicobacter pylori infection among school aged children in Alaska. Pediatrics. 2006; 117(3). Available at: www.pediatrics.org/cgi/content/full/117/ 3/e396

83. Dufour C, Brisigotti M, Fabretti G, Luxardo P, Mori PG, Barabino A. Helicobacter pylori gastric infection and sideropenic refractory anaemia. J Pediatr Gastroenterol Nutr. 1993;17: 225-227

84. Marignani M, Angeletti S, Bordi C, et al. Reversal of long standing iron deficiency anaemia after eradication of Helicobacter pylori. Scand J Gastroenterol. 1997;32:617-622

85. Annibale B, Capurso G, Lahner E, et al. Concomitant alterations in intragastric $\mathrm{pH}$ and ascorbic acid concentration in patients with Helicobacter pylori gastritis and associated iron deficiency anaemia. Gut. 2003;52:496-501

86. Ratledge C, Dover LG. Iron metabolism in pathogenic bacteria. Annu Rev Microbiol. 2000;54:881-941

87. Weinberg ED. Iron and susceptibility to infectious disease. Science. 1974; 184:952-956

88. Velayudhan J, Hughes NJ, McColm AA, et al. Iron acquisition and virulence in Helicobacter pylori: a major role for FeoB, a high-affinity ferrous iron transporter. Mol Microbiol. 2000;37: 274-286

89. Choe YH, Oh YJ, Lee NG, et al. Lactoferrin sequestration and its contribution to iron-deficiency anemia in Helicobacter pyloriinfected gastric mucosa. J Gastroenterol Hepatol. 2003;18: 980-985

90. Stoltzfus RJ, Chwaya HM, Tielsch JM, Schulze KJ, Albonico M, Savioli L. Epidemiology of iron deficiency anaemia in Zanzibari schoolchildren: the importance of hookworms. Am J Clin Nutr. 1997;65:153-159

91. Oppenheimer SJ. Iron and its relation to immunity and infec- 
tious disease. J Nutr. 2001;131(2S-2):616S-633S; discussion 633S-635S

92. Grantham-McGregor S, Ani C. A review of studies on the effect of iron deficiency on cognitive development in children. $J$ Nutr. 2001;131(2S-2):649S-666S; discussion 666S-668S

93. Rothenbacher D, Blaser MJ, Bode G, Brenner H. Inverse rela- tionship between gastric colonization of Helicobacter pylori and diarrheal illness in children: results of a population-based cross-sectional study. J Infect Dis. 2000;182:1446-1449

94. Perry S, Sanchez L, Yang S, Haggerty TD, Hurst P, Parsonnet J. Helicobacter pylori and risk of gastroenteritis. J Infect Dis. 2004; 190:303-310 


\section{Childhood Helicobacter pylori Infection and Growth Impairment in Developing Countries: A Vicious Cycle?}

Henry J. Windle, Dermot Kelleher and Jean E. Crabtree

Pediatrics 2007;119;e754-e759; originally published online Feb 26, 2007;

DOI: $10.1542 /$ peds. $2006-2196$

\section{Updated Information \\ \& Services}

References

Subspecialty Collections

Permissions \& Licensing

Reprints including high-resolution figures, can be found at:

http://www.pediatrics.org/cgi/content/full/119/3/e754

This article cites 91 articles, 28 of which you can access for free at:

http://www.pediatrics.org/cgi/content/full/119/3/e754\#BIBL

This article, along with others on similar topics, appears in the following collection(s):

Infectious Disease \& Immunity

http://www.pediatrics.org/cgi/collection/infectious_disease

Information about reproducing this article in parts (figures, tables) or in its entirety can be found online at:

http://www.pediatrics.org/misc/Permissions.shtml

Information about ordering reprints can be found online:

http://www.pediatrics.org/misc/reprints.shtml 